\title{
FLOOD PROFILES FOR CYPRESS CREEK, WEST-CENTRAL FLORIDA
}

\section{U.S. GEOLOGICAL SURVEY}

Water-Resources Investigations 78-8

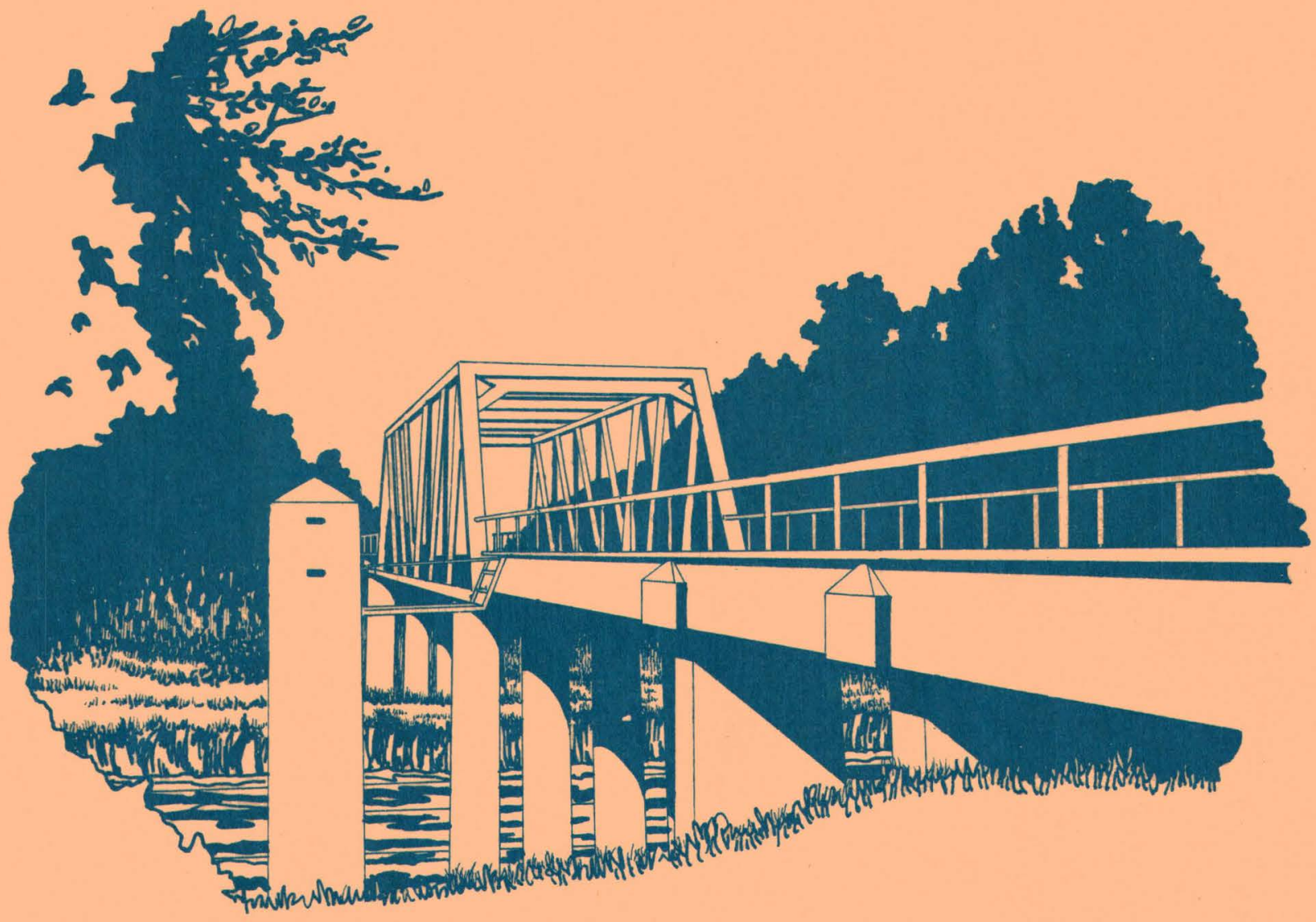

Prepared in cooperation with the SOUTHWEST FLORIDA WATER MANAGEMENT DISTRICT 


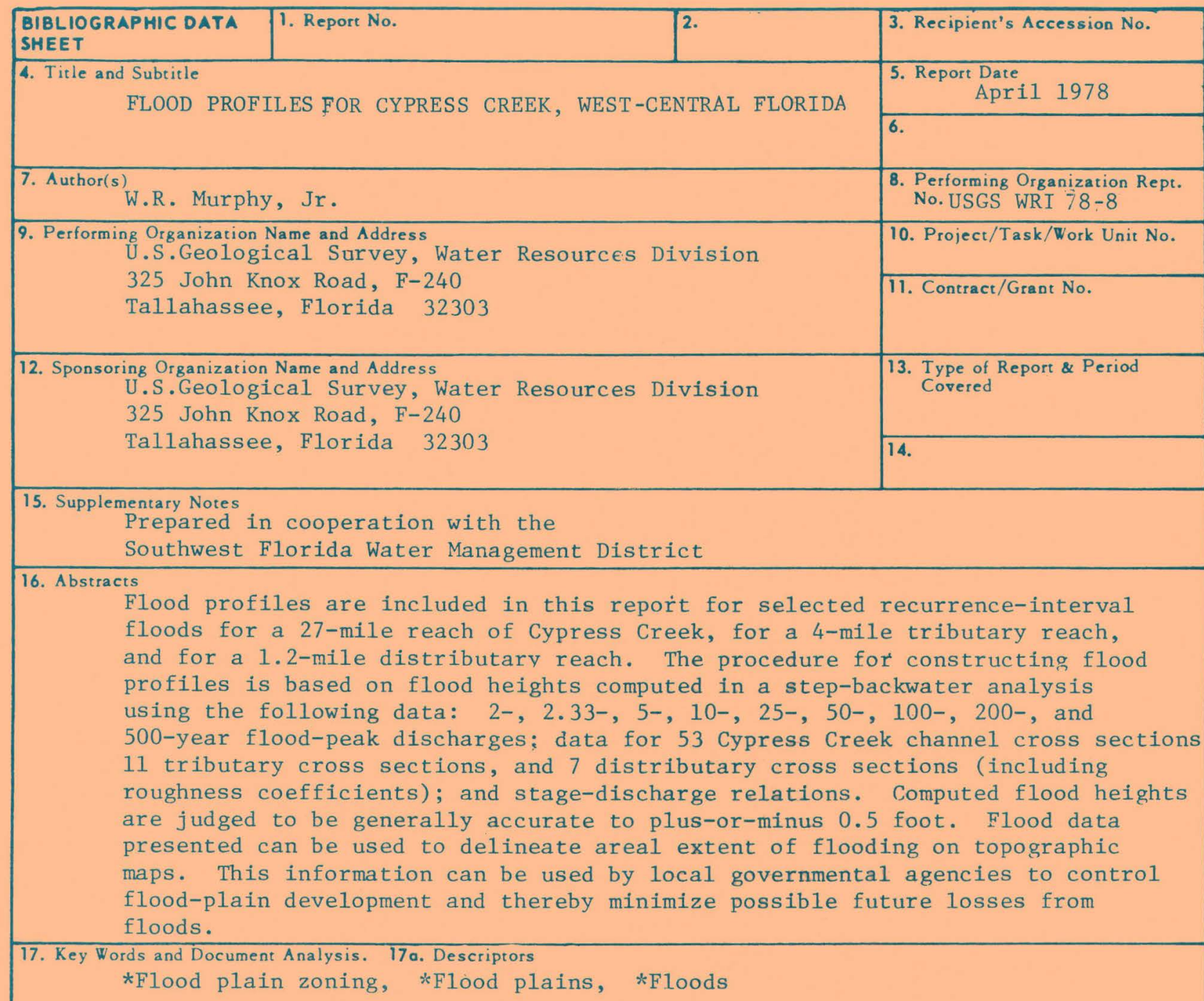

17b. Identifiers/Open-Ended Terms

Cypress Creek, Hillsborough County, Pasco County

17c. $\operatorname{COSATI}$ Field/Group

\begin{tabular}{|c|c|c|}
\hline $\begin{array}{l}\text { 18. Availability Statement } \\
\text { No restriction on distribution }\end{array}$ & $\begin{array}{l}\text { 19. Security Class (This } \\
\text { Report) } \\
\text { UNCLASSIEIED }\end{array}$ & $\begin{array}{l}\text { 21. No. of Pages } \\
35 \\
\end{array}$ \\
\hline & $\begin{array}{l}\text { 20. Security Class (This } \\
\text { Page } \\
\text { UNCLASSIFIED }\end{array}$ & 22. Price \\
\hline
\end{tabular}


FLOOD PROFILES FOR CYPRESS CREEK,

WEST-CENTRAL FL.ORIDA

By W. R. Murphy, Jr.

U.S. GEOLOGICAL SURVEY

Water-Resources Investigations 78-8

Prepared in cooperation with the

SOUTHWEST FLORIDA WATER MANAGEMENT DISTRICT 


\section{UNITED STATES DEPARTMENT OF THE INTERIOR}

CECIL D. ANDRUS, Secretary

GEOLOGICAL SURVEY

H. William Menard, Director

For additional information write to:

U.S. Geological Survey

325 John Knox Road, Suite F-240

Tallahassee, Florida 32303 
Glossary ...................................... v

Abstract $\ldots \ldots \ldots \ldots \ldots \ldots \ldots \ldots \ldots \ldots \ldots \ldots \ldots \ldots \ldots \ldots \ldots \ldots \ldots \ldots \ldots \ldots$

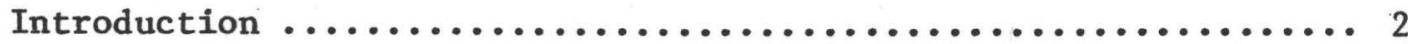

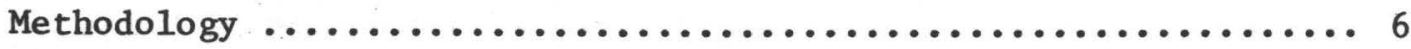

Areal flood-frequency relations $\ldots \ldots \ldots \ldots \ldots \ldots \ldots \ldots \ldots \ldots \ldots$

Flood-height computations $\ldots \ldots \ldots \ldots \ldots \ldots \ldots \ldots \ldots \ldots \ldots \ldots \ldots \ldots \ldots$

Cypress Creek ................................. 12

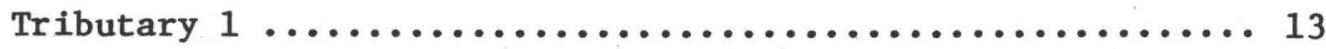

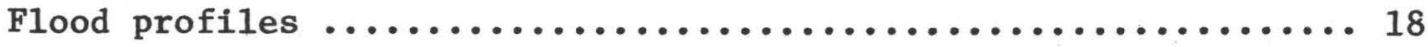

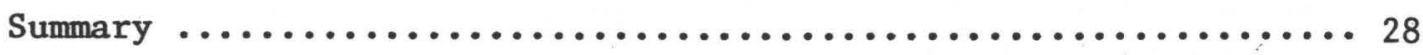

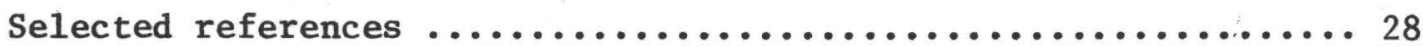

\section{ILLUSTRATIONS}

Figure

1. Map showing location of Cypress Creek study reach ....... 3

2. Map showing Cypress Creek study reach and approximate location of channel cross sections ................. 4-5

3. Map showing location of gaging stations used in multiple linear-regression analysis ....................... 8

4. Graph showing areal flood-frequency relations for Cypress

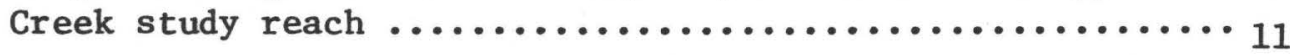

5. Graph showing 2.33-, 10-, 100-, and 500-year flood profiles for the Cypress Creek study reach ............. 19

6. Graph showing 2.33-, 10-, 100-, and 500-year flood profiles for Tributary 1 study reach ................. 24

7. Graph showing 2.33-, 10-, 100-, and 500-year flood profiles for the distributary ..................... 26 
TABLES

Table

Page

1. Cypress Creek streamflow records used $\ldots \ldots \ldots \ldots \ldots \ldots \ldots \ldots \ldots$

2. Areal flood-frequency equations ................... 10

3. Cypress Creek stage-discharge data used .............. 14

4. Cypress Creek peak discharges used in flood-height

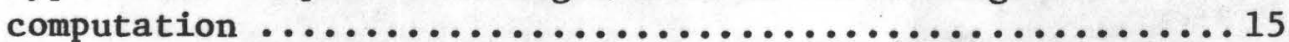

5. Tributary 1 peak discharges used in flood-height computation .................................... 16

6. Distributary peak discharges used in flood-height computation ................................ 17

7. Computed flood heights for selected recurrence-interval flood-peak discharges at 53 cross sections on Cypress Creek from mouth to State Road 52 .................. 20

8. Computed flood heights for selected recurrence-interval flood-peak discharges at 11 cross sections on Tributary 1..25

9. Computed flood heights for selected recurrence-interval flood-peak discharges_at 7 cross sections on the distributary

* $\quad * \quad * \quad * \quad * \quad * \quad * \quad * \quad * \quad * \quad * \quad * \quad *$

For use of those readers who may prefer to use metric units rather than U.S. customary units, the conversion factors for the terms used in this report are listed below:

U.S. customary units

cubic $_{3}$ foot per second $\left(\mathrm{ft}^{3} / \mathrm{s}\right)$

foot ( $f t)$

mile (mi)

square mile $\left(\mathrm{mi}^{2}\right)$

foot per mile ( $\mathrm{ft} / \mathrm{mi}$ )

inch (in)
Multiply by

0.02832

.3048

1. 609

2.590

.1894

25.40

\section{Metric units}

cubic meter ${ }_{3}$ per second $\left(\mathrm{m}^{3} / \mathrm{s}\right)$

meter (m)

kilometer $(\mathrm{km})$

square kilometer $\left(\mathrm{km}^{2}\right)$

meter per kilometer (m/km)

millimeter (mm) 
Some of the technical terms used in this report are defined here for convenience. See Dalrymple (1960) and Langbein and Iseri (1960) for additional information regarding flood-frequency analysis and associated terminology. Also, see the table for converting U.S. customary units to the International system of units (SI).

Discharge is the volume of water (or more broadly, total fluids), that passes a given point within a given period of time.

Drainage area of a stream at a specified location is that area enclosed by a topographic divide from which direct surface runoff from precipitation normally drains by gravity into the stream above the specified point.

Flood-frequency distribution is a graph showing the relation between the magnitude of floods and their return period or probability of being exceeded. The log-Pearson Type III method was used as a basis for determining flood-frequency relations. The method is described by the Water Resources Council (1976).

Flood height is the elevation of the water surface above a selected datum plane. Mean sea level datum plane of 1929 is used in this study. The terms "water-surface elevation" and "flood height" are used interchangeably in this report.

Flood profiles, as provided in this report, are plots of the watersurface elevation at flood stage versus distance, measured in the upstream direction. Profiles show crests along the study reach for flood-peak discharges of specified recurrence intervals.

Gaging station is a particular site on a stream, canal, lake, or reservoir where systematic observation of gage height or discharge are obtained.

Manning's roughness coefficient, $\underline{n}$, is a factor used with openchannel flow equations and is a measure of channel boundary roughness. Typical values of roughness are tabulated for various boundary conditions in most hydraulic texts. In studies such as this one, roughness coefficients are estimated from aerial photographs, available streamflow records and field site surveys.

Mean annual flood is a flood that, on the average, may be exceeded every 2.33 years; a flood that has a 42.9-percent chance of being exceeded any year. (Gumbel distribution having a fixed skew of 1.139.)

Recurrence interval, as applied to flood events such as flood-peak discharge, is the average interval of time within which a flood of specified magnitude will be exceeded at least once (Riggs, 1968). For ex- 
ample, the 100-year flood is a flood discharge that has a 1-percent chance of being exceeded in any year.

Regression analysis as used in this report, is a statistical procedure used to determine the relationship between selected recurrenceinterval flood-peak discharges (dependent variable) and watershed parameters (independent variable) on a regional basis. This relation is expressed as an equation and is used for estimating the magnitude of selected recurrence-interval floods at gaged and ungaged sites.

Stage-discharge rating is a relation describing discharge as a function of stream stage. Stage-discharge ratings are empirical relations and are normally developed by actual field measurement of discharge and stage. For some hydraulic conditions, approximate stage-discharge ratings can be calculated using empirical equations describing open-channel flow, knowing channel-geometry data for a specified stream site. 


\section{FLOOD PROFILES FOR CYPRESS CREEK, WEST-CENTRAL FLORIDA}

By

W. R. Murphy, Jr.

\section{ABSTRACT}

Flood profiles are included in this report for selected recurrenceinterval floods for a 27-mile reach of Cypress Creek, for a 4-mile tributary reach, and for a 1.2-mile distributary reach.

The procedure for constructing flood profiles is based on flood heights computed in a step-backwater analysis using the following data: 2-, 2.33-, 5-, 10-, 25-, 50-, 100-, 200-, and 500-year flood-peak discharges; data for 53 Cypress Creek channel cross sections, 11 tributary cross sections, and 7 distributary cross sections (including, roughness coefficients); and stage-discharge relations. Computed flood heights are judged to be generally accurate to plus-or-minus 0.5 foot.

Flood data presented can be used to delineate areal extent of flooding on topographic maps. This information can be used by local governmental agencies to control flood-plain development and thereby minimize possible future losses from floods. 


\section{INTRODUCTION}

The Cypress Creek Basin lies in parts of Pasco and Hillsborough Counties, Florida (fig. 1). Cypress Creek originates in south-central Pasco County and flows south through numerous interconnected swamps and despression areas to Hillsborough River (fig. 1). The basin is about $164 \mathrm{mi}^{2}$ in size.

Developments in the basin are increasing. Agricultural developments consist mainly of pasture and citrus groves. Urban development, consisting of trailer parks and small residential sub-divisions, are located in the lower basin, particularly in Hillsborough County. Many of these developments are located in flood-prone areas.

Cypress Creek flooding includes areas adjacent to the stream channel, outlying swampy and depression areas, and other areas inundated by backwater from Hillsborough River. Flooding in these areas results from thunderstorms, tropical depressions, and hurricanes; all bring large rainfall amounts in short time periods. In 1959 and 1960, extensive flooding occurred in the basin and caused considerable damage to area agriculture.

Cypress Creek flooding is related to flood-plain characteristics which enhance flood-water detention and slow-flood recession. These characteristics include large surface storage, wide overflow plains, and low topographic relief. Flood plains range in width from several hundred feet to more than $2 \mathrm{mi}$. Topographic relief from flood-plain edge to stream channel ranges from 3 to $5 \mathrm{ft}$, and stream slope averages about $1.4 \mathrm{ft} / \mathrm{mi}$.

Average annual rainfall for the basin is about $55 \mathrm{in}$, most occurring from June through September. Annual runoff from the basin ranges from 6 to 9 in/yr, whereas annual runoff from most other area streams varies from 10 to $15 \mathrm{in} / \mathrm{yr}$.

The Southwest Florida Water Management District has long recognized the need for flood-plain management information, and in 1973 entered into a cooperative program with the U.S. Geological Survey to define probable flood levels along principal streams in west-central Florida, including Cypress Creek. The Water Management District furnished photo-base topographic maps, and stream and valley cross-section data used in the study.

The purpose of this investigation is to determine the 2-, 2.33-, 5-, 10-, 25-, 50-, 100-, 200-, and 500-year recurrence-interval flood heights and prepare flood profiles for (1) a 27-mi reach of Cypress Creek from State Road 52 in Pasco County to the mouth, at Hillsborough River, in Hillsborough County; (2) the lower $4 \mathrm{mi}$ of Tributary 1, a tributary to the upper part of the Cypress Creek study reach; and (3) a 1.2-mi distributary connecting Tributary 1 and Cypress Creek (fig. 2). 


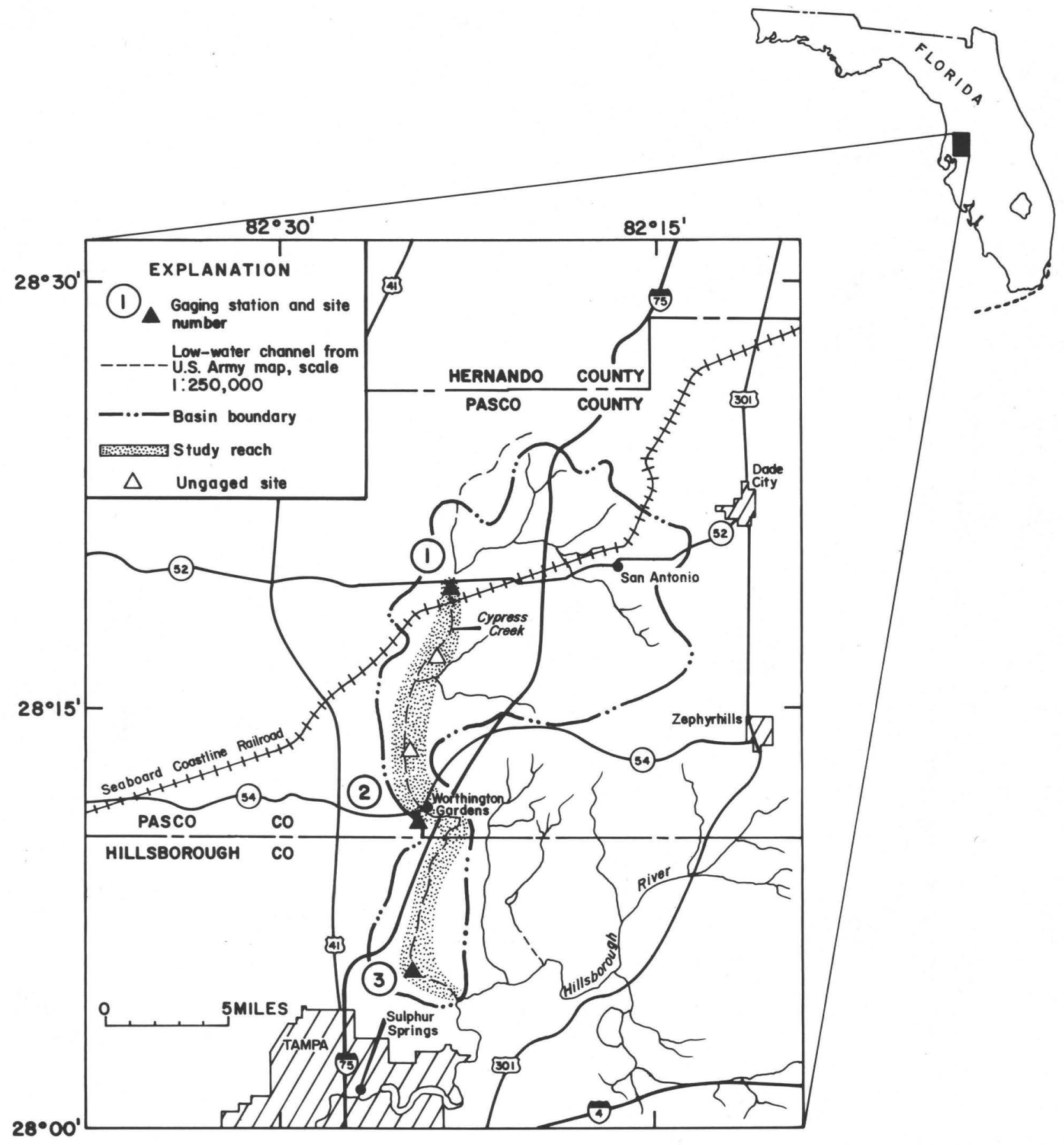

Figure 1 -- Location of Cypress Creek study reach. 


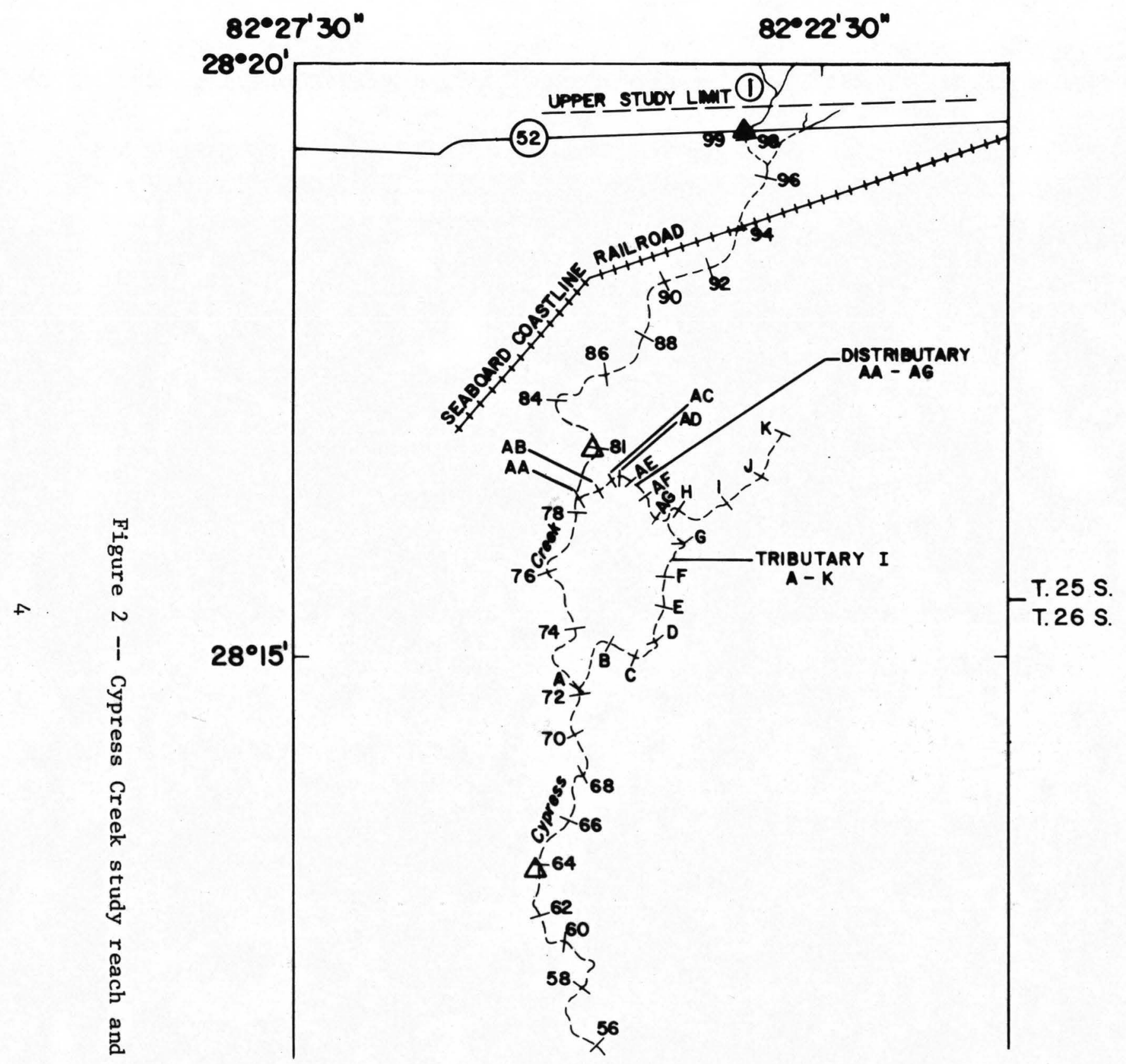




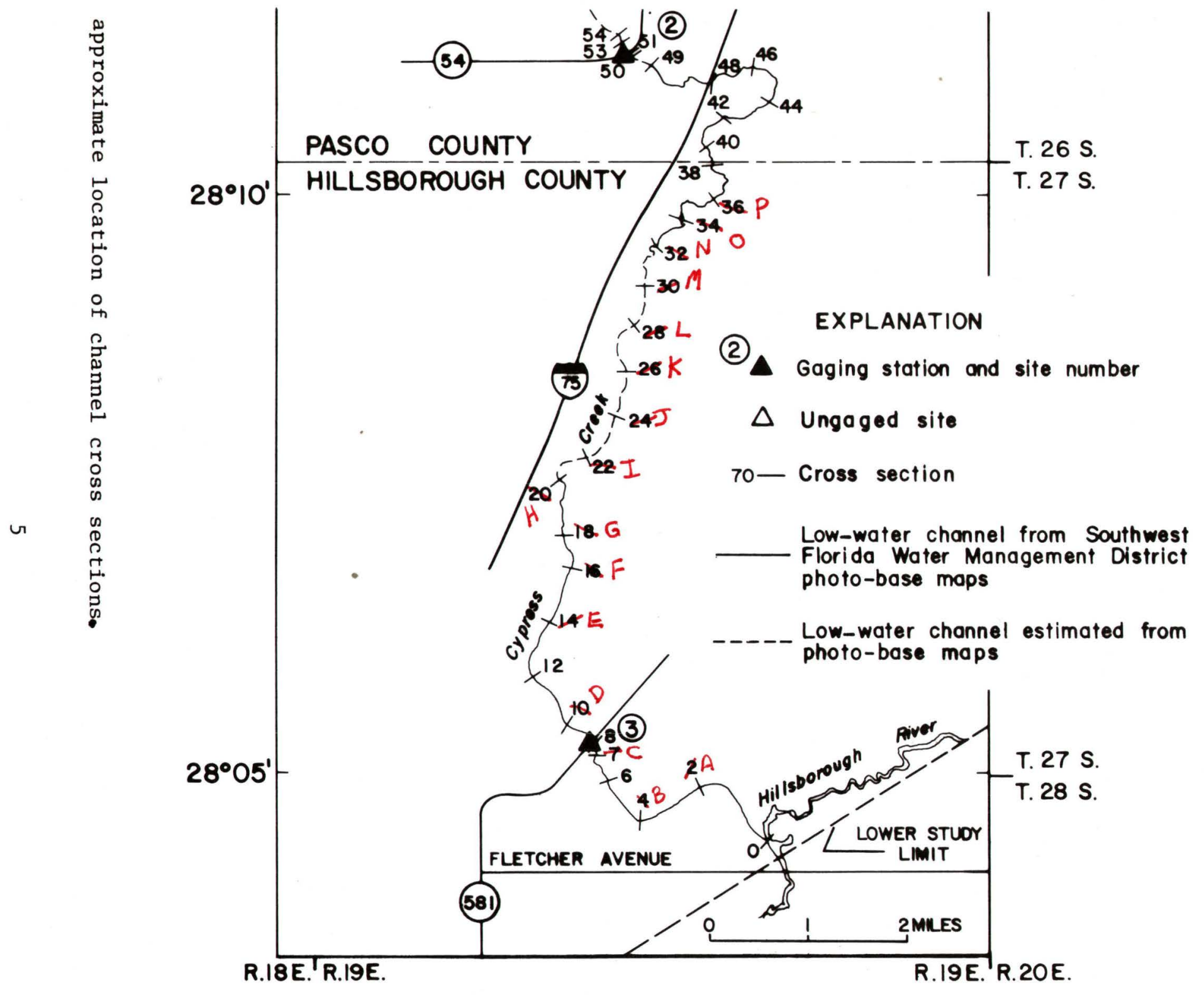




\section{METHODOLOGY}

Flood heights and profiles presented in this report represent flood crests for selected recurrence-interval floods along the study reach. Flood heights (crests) were computed for 53 Cypress Creek, 11 Tributary 1 , and 7 distributary channel cross sections located along the study reaches. Flood heights for selected recurrence intervals were plotted on a graph versus measured distance of stream-channel cross section above stream mouth and connected to form profiles.

Flood heights were calculated in a step-backwater analysis using selected recurrence-interval flood-peak discharges. The Geological Survey step-backwater computer program used (Shearman, 1976) is similar to a procedure described by Chow (1959) and Posey (1950). The technique requires a beginning flood-peak discharge and corresponding flood stage. Using these data, a velocity head is calculated for the initial downstream cross section, and a water-surface elevation (flood height) is assumed at the next upstream cross section. Head losses due to friction between these two cross sections are calculated and an energy balance is computed. When the energy balance falls outside selected tolerance limits, the upstream flood height is adjusted, and energy calculation and balance tests are repeated until an acceptable balance is achieved. This procedure is repeated for remaining channel cross-section pairs, beginning at the next upstream cross section and proceeding to the upstream end of the study reach.

Step-backwater computations were verified by use of stage-discharge ratings available at gaging stations located along the study reach. Data available for these stations are summarized in table 1. The Sulphur Springs station, located near the beginning of the study reach (site 3, fig. 2), has 12 years of record; the Worthington Gardens station (site 2, fig. 2), located near the middle of the study reach end, has 9 years of record; and the San Antonio station (site 1, fig. 2) has 11 years of record.

Flood-peak discharges used in the step-backwater analyses were taken from areal flood-frequency relations. Development of these relations is discussed in the following report section.

\section{AREAL FLOOD-FREQUENCY RELATIONS}

Areal flood-frequency relations used in the study are based on results of a regional flood study of long-term records for 20 streamflow stations in the west-central Florida area. A11 area stations having at least 20 years of record were used in the study; station locations are shown in figure 3 . 
Table 1. -- Cypress Creek streamflow records used

\begin{tabular}{|c|c|c|c|c|}
\hline Site ${ }^{1}$ & $\begin{array}{l}\text { Gaging } \\
\text { station }\end{array}$ & Location & $\begin{array}{l}\text { Drainage } \\
\text { area }_{\left(\mathrm{mi}^{2}\right)}\end{array}$ & $\begin{array}{l}\text { Period of } \\
\text { record used }\end{array}$ \\
\hline 1 & $\begin{array}{l}\text { Cypress Creek } \\
\text { near San } \\
\text { Antonio }\end{array}$ & $\begin{array}{l}\text { at State Road } 52,6.8 \\
\text { mi west of San Antonio, } \\
\text { and } 25 \mathrm{mi} \text { above mouth }\end{array}$ & 56 & $1972-76$ \\
\hline 2 & $\begin{array}{l}\text { Cypress Creek } \\
\text { at Worthington } \\
\text { Gardens }\end{array}$ & $\begin{array}{l}\text { at State Road } 54,0.2 \\
\text { mi southwest of Worth- } \\
\text { ington Gardens, and } 14 \\
\text { mi above mouth }\end{array}$ & 117 & $\begin{array}{l}1964-76 \\
1970-71 \\
1974-76\end{array}$ \\
\hline 3 & $\begin{array}{l}\text { Cypress Creek } \\
\text { near Sulphur } \\
\text { Springs }\end{array}$ & $\begin{array}{l}\text { at State Road } 581,5.0 \mathrm{mi} \\
\text { northeast of Sulphur } \\
\text { Springs, and } 2.5 \mathrm{mi} \\
\text { above mouth }\end{array}$ & 160 & $\begin{array}{l}1960, \\
1965-76\end{array}$ \\
\hline
\end{tabular}

$1_{\text {See figures } 1 \text { and } 2 .}$ 


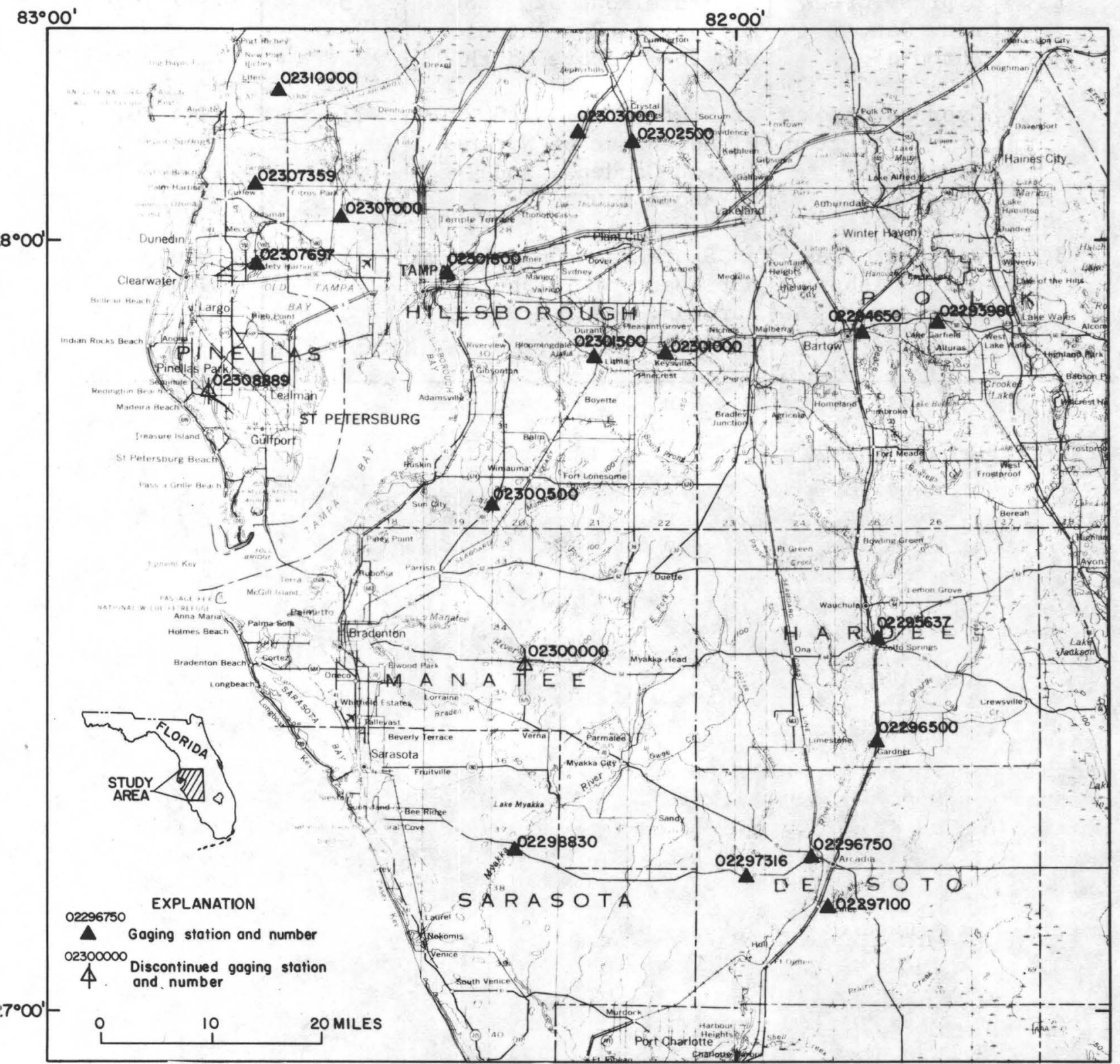

Figure 3.--Location of gaging stations used in multiple linear-regression analysis. 
Flood-frequency distributions were obtained for each station in a log-Pearson Type III analysis using Water Resources Council (1976) gưidelines and a generalized map skew coefficient of -0.05 . Regional flooid relations were developed in a multiple linear-regression analysis of selected recurrence-interval flood-peak discharges (from the log-Pearson Type III distributions) and selected basin parameters. Basin parameters used in the regression include drainage area, stream length and slope, and percent of basin as lake and swamp area. A11 parameters were significant at the 5 percent level. The ranges in basin parameters used are summarized in the following table:

Basin Parameter

Drainage area

Length

Slope

Lake and swamp area
Range

9.0 to $1,367 \mathrm{mi}^{2}$

6.2 to $140 \mathrm{mi}$

1.2 to $5.0 \mathrm{ft} / \mathrm{mi}$

4.5 to 28.7 percent

Regional flood relations, standard errors of estimate, and multiple correlation coefficients obtained in the regression study are summarized in table 2. The average standard error of estimate for regional flood relations is 25.8 percent. The average multiple correlation coefficient is 0.98 .

The standard error of estimate (Ezekiel, 1950) is the standard deviation of residuals about the regression line; the multiple correlation coefficient indicates the degree of linear relationship between peak discharge and basin parameters used. A complete discussion of multiple linear-regression analysis is given by Bryant (1960). Application of regression analysis in a similar hydrologic study is given by Rabon (1971).

Log-Pearson Type III station-frequency relations differ from the regression estimates. Therefore, Cypress Creek areal flood-frequency relations shown in figure 4 are based on weighted flood-frequency estimates for the San Antonio, Worthington Gardens, and Sulphur Springs streamflow stations. The weighting procedure used (weighting of independent estimates) is described by the Water Resources Council (1976). Weighting factors used include years of record for log-Pearson Type III estimates and equivalent years of record for regression estimates. Equivalent years of record (table 2) for regression estimates were determined using a procedure described by Hardison (1969).

Ungaged sites selected are located between the Worthington Gardens and San Antonio stations, at cross sections 81 and 64 , and have drainage areas of 70 and $102 \mathrm{mi}^{2}$, respectively. Regression estimates determined for these sites were adjusted using gaged site ratios of weighted stationfrequency estimates to regional estimates. 
Table 2. -- Areal flood-frequency equations

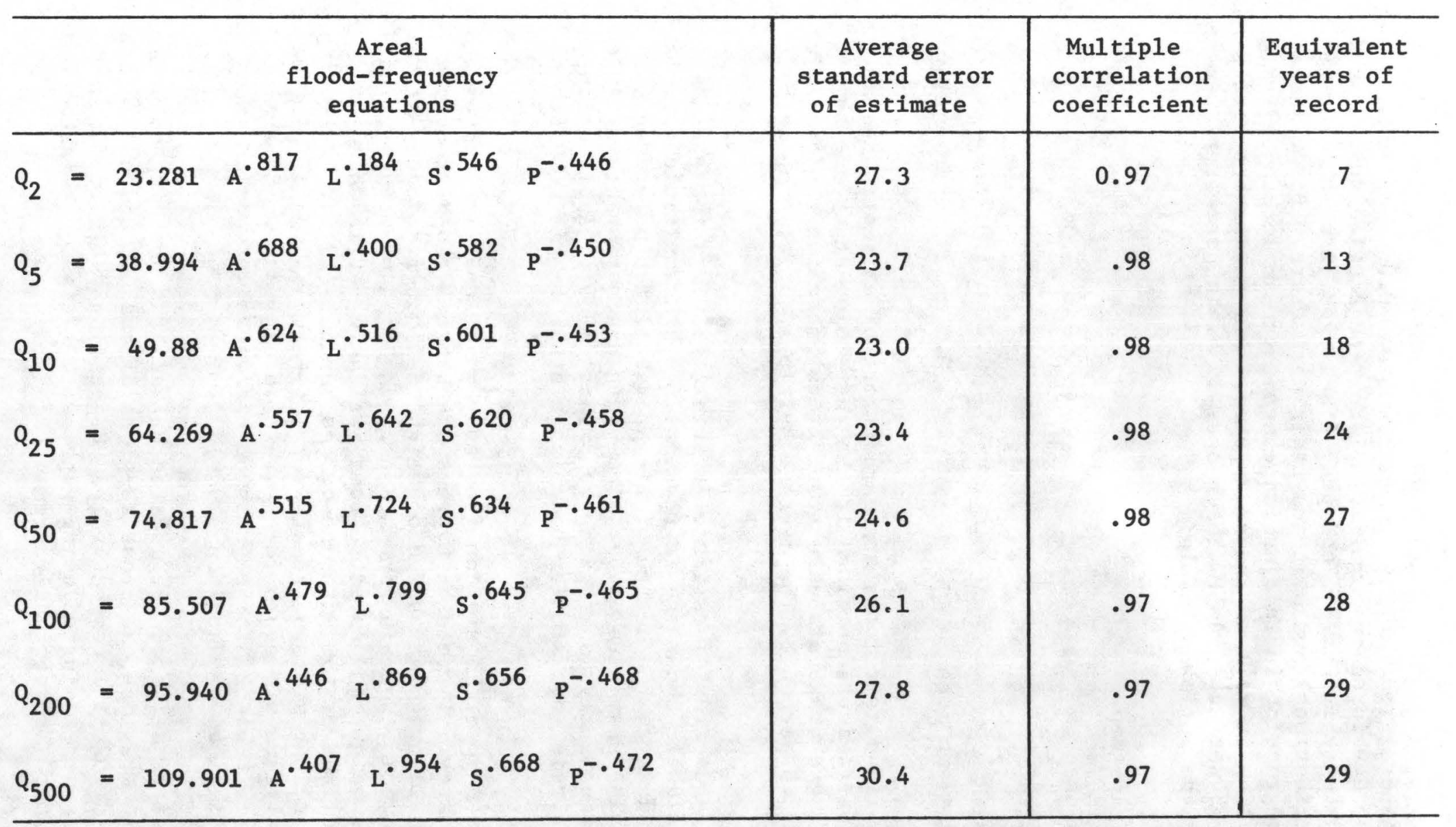

A - Drainage area in $\mathrm{mi}^{2}$

$\mathrm{S}$ - Main-channel slope, in $\mathrm{ft}$ per $\mathrm{mi}$ is the average slope of the main channel between points 10 and 85 percent of the distance upstream from the gaging site to the basin border
L - Main channel length in $\mathrm{mi}$ from gaging site to basin border

$P$ - Percent of drainage basin as lakes and swamps 


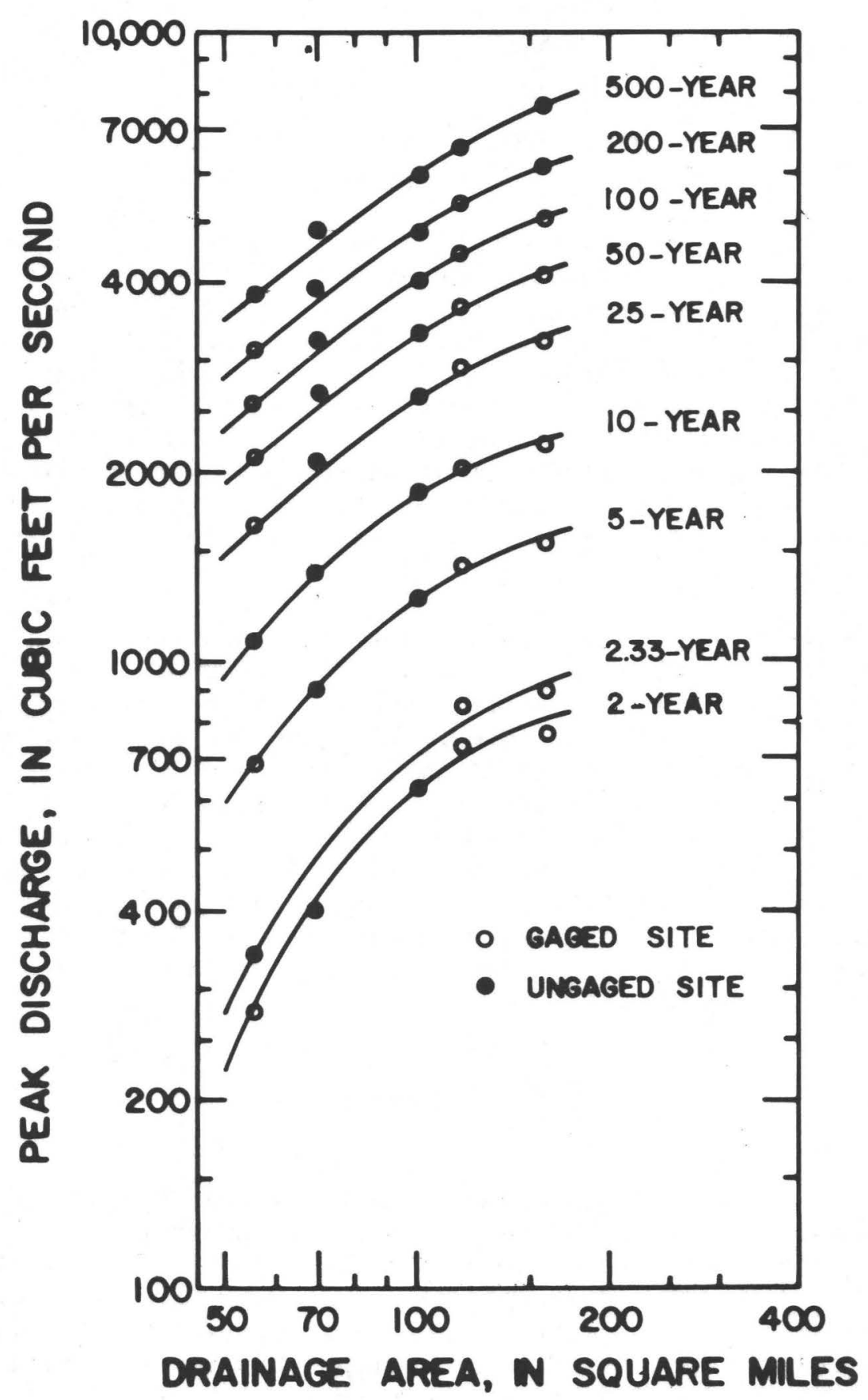

Figure 4 -- Areal flood-frequency relations for Cypress Creek study reach 
Areal flood-frequency relations were developed by plotting weighted recurrence-interval flood-peak discharges for gaged and ungaged sites versus respective drainage areas on a logarithmic graph. Smooth curves were drawn through plotted points of equal recurrence interval to form areal relations shown in figure 4 .

\section{FLOOD-HEIGHT COMPUTATIONS}

Flood heights were computed for the Cypress Creek main stem, and for Tributary 1 and the distributary, located in the middle basin, in stepbackwater analyses using areal flood-peak discharges having recurrence intervals of $2,2.33,5,10,25,50,100,200$, and 500 years. Additional data used in the analyses include: (1) land-surface elevation data and roughness coefficients for 53 cross sections on the Cypress Creek main stem, 11 cross sections for Tributary 1, and 7 cross sections on the distributary; (2) beginning flood stages at the mouths of Cypress Creek, Tributary 1, and the distributary; and (3) stage-discharge relations available at the Sulphur Springs, Worthington Gardens, and San Antonio gaging stations.

Stream and valley cross-section geometry data were compiled from detailed photo-base topographic maps (scale 1:2,400 and $1 \mathrm{ft}$ contours) and from field measurements. Stream and valley roughness coefficients were selected from photo-base topographic maps and field survey data. Cross-section distances upstream from the mouths of Cypress Creek, Tributary 1, and the distributary were scaled from the 1:2,400 photobase topographic maps along the low-water channel. For much of the study reach, no low-water channel was indicated and the low-water channel location was estimated. Accurate location of cross sections on less detailed maps is very difficult. Therefore, cross-section locations indicated on figure 2 are approximate. Average distance between cross sections for Cypress Creek is about $0.5 \mathrm{mi}$.

\section{Cypress Creek}

Flood profiles were developed for Hillsborough River, from Tampa Reservoir Dam upstream to Fletcher Avenue, by Turner (1974). These profiles were continued upstream about $1 \mathrm{mi}$ by step-backwater method to the mouth of Cypress Creek. Corresponding recurrence-interval flood elevations for Hillsborough River at the mouth of Cypress Creek were used as starting elevations for Cypress Creek step-backwater computations. The 200- and 500-year starting elevations were taken from extension of a graph of frequency elevations. Starting elevations used generally agree with U.S. ArmyCorps of Engineers (Jacksonville) data for the area (R. Hilton, oral commun., 1975). 
Stage-discharge ratings used in the study required extensions to include selected floods. The ratings were extended by step-backwater computations, verified up to the highest discharge measured at the gaging stations. Stage-discharge data used in the study, including rating extensions, are listed in table 3.

Recurrence-interval flood-peak discharges used in the step-backwater analyses were taken from figure 4. Drainage areas were determined at road crossings or at the mouths of tributaries along the study reach. Peak discharges were adjusted for drainage area changes of 4 to 30 percent. Drainage areas used to obtain peak discharges are listed in table 4 .

Stage-discharge relations for the gaging stations on Cypress Creek were used in verifying roughness coefficients. Values of roughness coefficient were adjusted to obtain agreement between computed flood heights and gaging station stage-discharge ratings.

\section{Tributary 1}

Tributary 1 enters the upper part of the Cypress Creek study reach, just upstream from cross section 72 (fig. 2). The study reach of Tributary 1 extends approximately $4 \mathrm{mi}$ upstream from Cypress Creek to the center of section 36, T25S, R19E. Tributary 1 flow is diverted, from a point between cross sections $\mathrm{G}$ and $\mathrm{H}$, through a distributary channe1, entering Cypress Creek at a point just upstream from cross section 78 (fig. 2).

Recurrence-interval flood-peak discharges used in computing Tributary 1 flood heights were calculated using areal flood-frequency equations (table 2). Areal flood-peak discharges used for flood-height computations for the distributary and Tributary 1 (downstream from the distributary) were adjusted so that distributary and Tributary 1 flood heights matched at their confluence (fig. 2). Cypress Creek flood heights for cross sections 72 and 78 were used as respective starting elevations for Tributary 1 and distributary step-backwater computations. At their confluence with Cypress Creek, the distributary 2-year flood discharge was 55 percent of Tributary 1 2-year flood discharge. The 10-year discharge was 70 percent and the 500-year discharge was 35 percent. The diversion amount is controlled by a graded road crossing at Tributary 1 cross section G (just downstream from the distributary). Tributary 1 and distributary recurrence-interval peak discharges used in step-backwater computations are summarized in tables 5 and 6 , respectively. 
Table 3. -- Cypress Creek stage-discharge data used

[Stage in feet above mean sea level. Discharge in cubic feet per second.]

\begin{tabular}{|c|c|c|c|c|c|c|c|}
\hline \multirow{2}{*}{$\begin{array}{c}\text { Recurrence } \\
\text { interval } \\
\text { (yrs) }\end{array}$} & \multirow{2}{*}{$\frac{\text { At mouth }}{1 /}$} & \multicolumn{2}{|c|}{ Sulphur Springs $\frac{2 /}{}$} & \multicolumn{2}{|c|}{ Worthington Gardens $\frac{3}{}$} & \multicolumn{2}{|c|}{ San Antonio $4 /$} \\
\hline & & Stage & Discharge & Stage & Discharge & Stage & Discharge \\
\hline 2 & 26.9 & 31.0 & 805 & 50.7 & 700 & 74.4 & 280 \\
\hline 2.33 & 27.6 & 31.3 & 930 & 51.1 & 800 & 74.6 & 340 \\
\hline 5 & 30.2 & 32.4 & 1580 & 53.1 & 1380 & 75.2 & 690 \\
\hline 10 & 32.1 & $a_{33.3}$ & 2270 & $a_{54.7}$ & 2000 & $a_{75.6}$ & 1070 \\
\hline 25 & 34.4 & $a_{35.0}$ & 3300 & $a_{56.4}$ & 2880 & $a_{75.9}$ & 1640 \\
\hline 50 & 36.1 & $a_{36.5}$ & 4230 & $a_{57.7}$ & 3600 & $a_{76.3}$ & 2120 \\
\hline 100 & 38.3 & $a_{38.5}$ & 5200 & $a_{58.8}$ & 4400 & $a_{76.6}$ & 2570 \\
\hline 200 & 40.0 & $a_{40.1}$ & 6200 & $a_{59.8}$ & 5300 & $a_{76.8}$ & 3100 \\
\hline 500 & 42.0 & $a_{42.1}$ & 7800 & $a_{61.3}$ & 6550 & $a_{77.0}$ & 3800 \\
\hline
\end{tabular}

1/ Cypress Creek at Hillsbórough River, stage data taken from results of Hillsborough River floodheight computations.

2/ Site 3 , figures 1 and 2.

3/ Site 2, figures 1 and 2 .

4/ Site 1 , figures 1 and 2 .

$\underline{5}$ / Stage values affected by backwater from Hillsborough River.

a Stage values from rating extensions determined as part of step-backwater computations. 
Table 4. -- Cypress Creek peak discharges used in flood-height computation

\begin{tabular}{|c|c|c|c|c|c|c|c|c|c|c|}
\hline \multirow{2}{*}{$\begin{array}{l}\text { Cross } \\
\text { sections }\end{array}$} & \multirow{2}{*}{$\begin{array}{c}\text { Drainage } \\
\text { aréa } \\
\left(\mathrm{mi}^{2}\right)\end{array}$} & \multicolumn{9}{|c|}{$\begin{array}{l}\text { Peak discharges, in cubic feet per second, } \\
\text { for indicated recurrence interval, in years }\end{array}$} \\
\hline & & 2 & 2.33 & 5 & 10 & 25 & 50 & 100 & 200 & 500 \\
\hline $2-16$ & 164 & 805 & 930 & 1580 & 2270 & 3300 & 4230 & 5200 & 6200 & 7800 \\
\hline $18-26$ & 134 & 745 & 855 & 1470 & 2120 & 3050 & 3850 & 4740 & 5650 & 7050 \\
\hline $28-49$ & 122 & 710 & 810 & 1410 & 2030 & 2930 & 3650 & 4500 & 5400 & 6700 \\
\hline $50-72$ & 117 & 700 & 800 & 1380 & 2000 & 2880 & 3600 & 4400 & 5300 & 6550 \\
\hline $74-78$ & 76 & 460 & 540 & 980 & 1480 & 2160 & 2720 & 3340 & 4000 & 4900 \\
\hline $81-92$ & 70 & 410 & 485 & 900 & 1370 & 2040 & 2550 & 3130 & 3750 & 4600 \\
\hline // & 56 & 280 & 340 & 690 & 1070 & 1640 & 2120 & 2570 & 3100 & 3800 \\
\hline
\end{tabular}

I/ State Road 52 . 
Table 5. -- Tributary 1 peak discharges used in flood-height computation

\begin{tabular}{|c|c|c|c|c|c|c|c|c|c|c|}
\hline \multirow{2}{*}{$\begin{array}{l}\text { Cross } \\
\text { sections }\end{array}$} & \multirow{2}{*}{$\begin{array}{c}\text { Drainage } \\
\text { area } \\
\left(m i^{2}\right)\end{array}$} & \multicolumn{9}{|c|}{$\begin{array}{l}\text { Peak discharge, in cubic feet per second, } \\
\text { for indicated recurrence interval, in years }\end{array}$} \\
\hline & & 2 & 2.33 & 5 & 10 & 25 & 50 & 100 & 200 & 500 \\
\hline$A-C$ & 23.6 & 84 & 90 & 120 & 140 & 230 & 290 & 385 & 530 & 760 \\
\hline $\mathrm{D}, \mathrm{E}$ & 21.3 & 76 & 80 & 105 & 120 & 200 & 256 & 340 & 480 & 460 \\
\hline$F, G$ & 19.2 & 65 & 68 & 87 & 94 & 170 & 216 & 294 & 415 & 330 \\
\hline $\mathrm{H}, \mathrm{I}$ & 16.9 & 122 & 132 & 200 & 267 & 346 & 405 & 480 & 605 & 750 \\
\hline $\mathrm{J}, \mathrm{K}$ & 15.7 & 92 & 97 & 143 & 183 & 230 & 260 & 310 & 375 & 450 \\
\hline
\end{tabular}


Table 6. -- Distributary peak discharges used in flood-height computation

\begin{tabular}{|c|c|c|c|c|c|c|c|c|c|}
\hline \multirow{2}{*}{$\begin{array}{l}\text { Cross } \\
\text { section }\end{array}$} & \multicolumn{9}{|c|}{$\begin{array}{l}\text { Peak diversion, in cubic feet per second, } \\
\text { for indicated recurrence interval, in years }\end{array}$} \\
\hline & 2 & 2.33 & 5 & 10 & 25 & 50 & 100 & 200 & 500 \\
\hline $\mathrm{AA}-\mathrm{AG}$ & 80 & 90 & 150 & 220 & 240 & 260 & 280 & 300 & 310 \\
\hline
\end{tabular}


Computed flood heights for the Cypress Creek and Tributary 1 reaches and the distributary are listed in tables 7-9, respectively. Cross-section numbers of letters in tables 7-9 refer to stream-channel cross sections shown in figure 2. Distances upstream from the mouth at which land-section lines cross the stream channel are also shown in tables 7-9.

Selected recurrence-interval flood profiles for the Cypress Creek and Tributary 1 study reaches and the distributary under present (1977) conditions, are shown in figures 5-7, respectively. Some recurrenceinterval flood profiles were not plotted on figures 5-7 because they are very near those plotted and can be interpolated from data listed in tables 7-9. Location of land section, township and range division lines are indicated on figures 5-7, near the top border. Cross sections are indicated near the lower border of figures 5-7.

The flood data shown in tables 7-9 may be used to delineate flood boundaries on topographic maps. These boundaries would indicate the areal extent of flooding adjacent to the Cypress Creek main stem and Tributary 1 study reaches and the distributary. The State Road 581 Cypress Creek bridge and the road near the bridge are expected to be inundated as indicated in table 7 .

The accuracy of the computed flood heights listed in tables 5-7 depends on the accuracy of many hydrologic input parameters. The important ones include cross-section, roughness-coefficient, and flood-frequency data used. The computed flood elevations are judged to be accurate to within $-0.5 \mathrm{ft}$. Additional urbanization and other manmade changes in the basin may change flood-peak discharges and flood-profile elevations. 


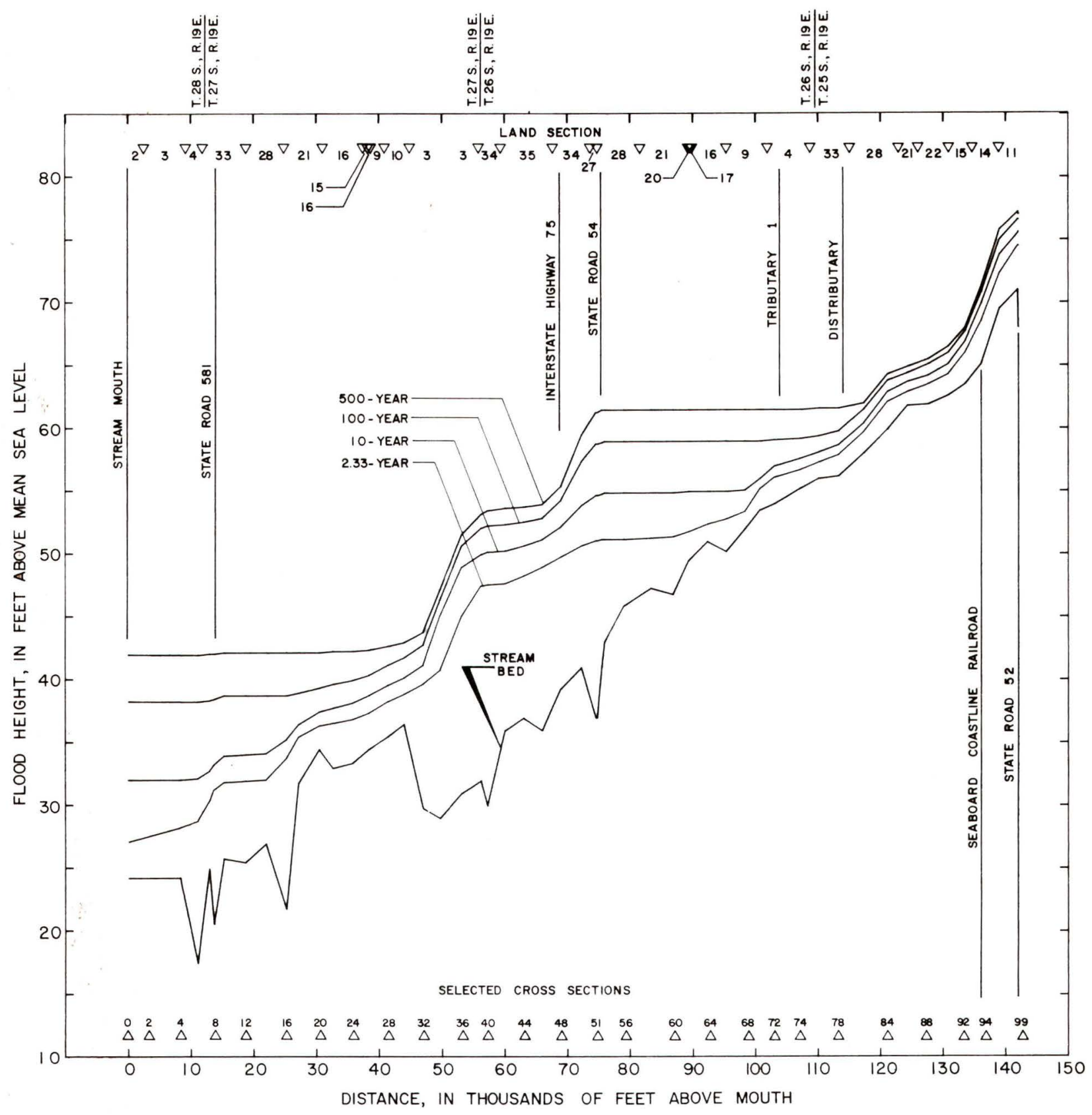

Figure 5,--2,33-, 10-, 100-, and 500-year flood profiles for the cypress creek study reach. 
Table 7. -- Computed flood helghts for selected recurrence-interval flood-peak discharges at 53 cross sections on Cypress Creek from mouth to State Road 52

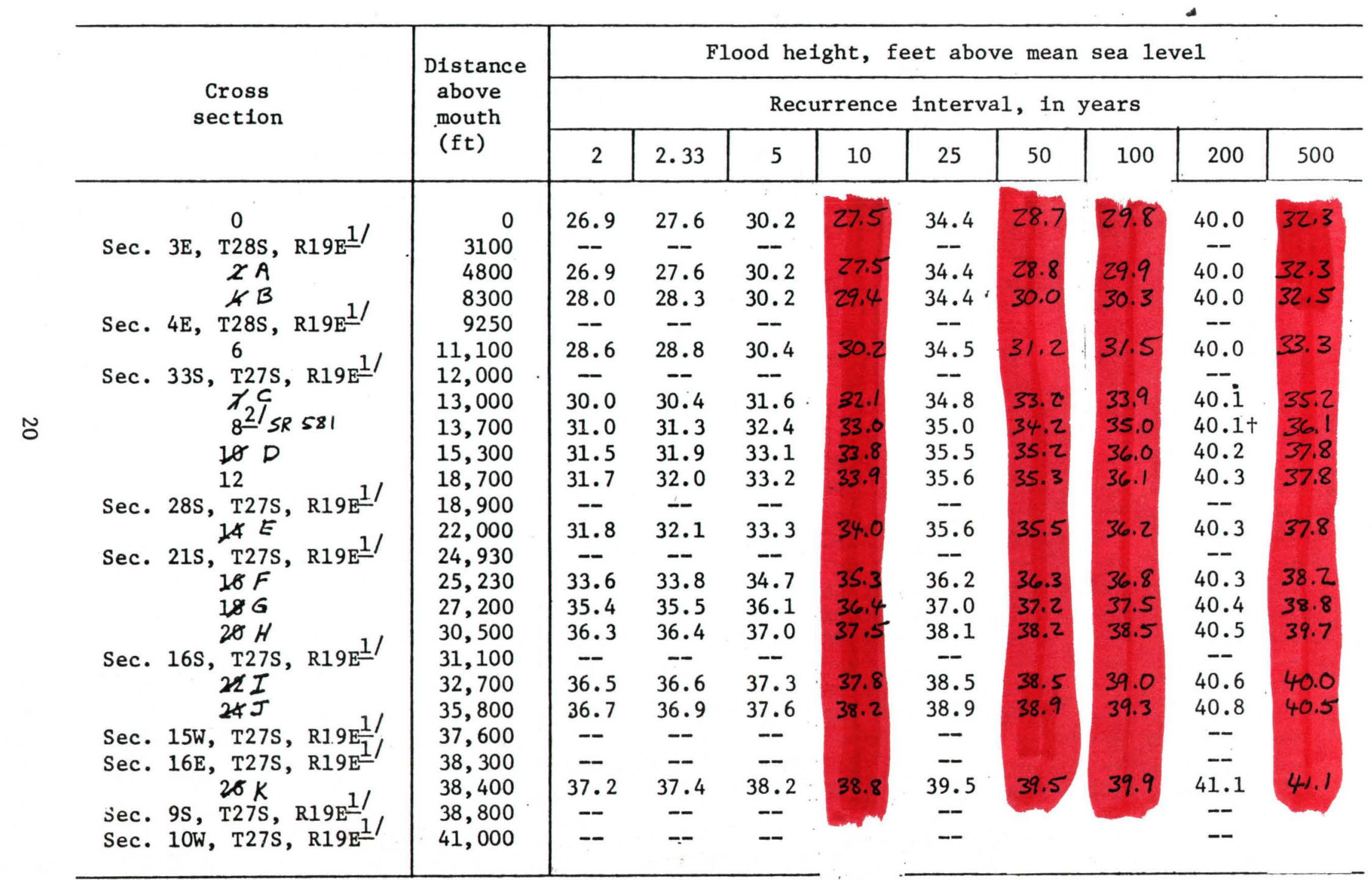


Table 7. -- Computed flood helghts for selected recurrence-interval flood-peak discharges at 53 cross sections on Cypress Creek from mouth to State Road 52 - continued

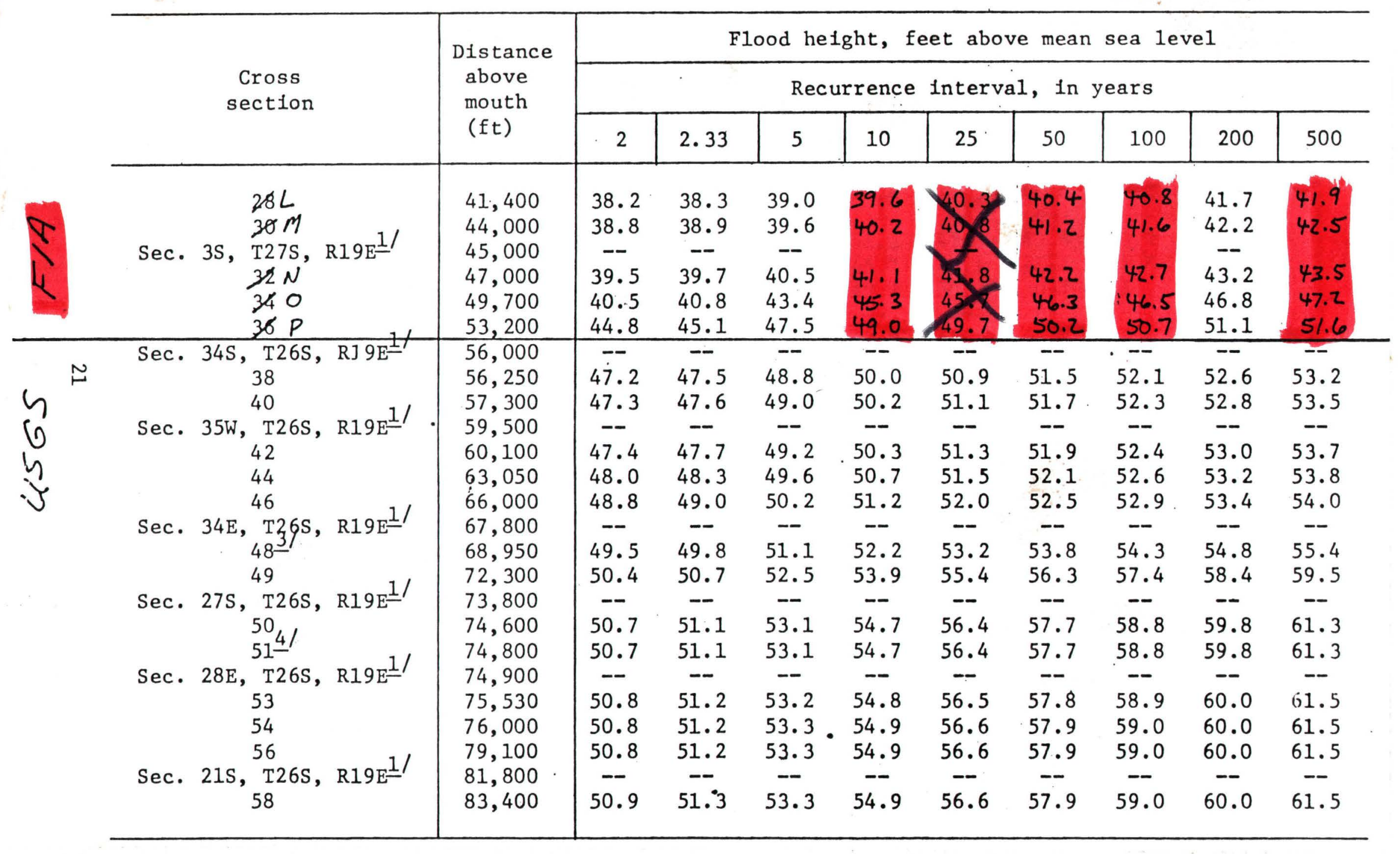


Table 7. -- Computed flood heights for selected recurrence-interval flood-peak discharges at 53 cross sections on Cypress Creek from mouth to State Road 52 - continued

\begin{tabular}{|c|c|c|c|c|c|c|c|c|c|c|}
\hline \multirow{3}{*}{$\begin{array}{l}\text { Cross } \\
\text { section }\end{array}$} & \multirow{3}{*}{$\begin{array}{l}\text { Distance } \\
\text { above } \\
\text { mouth } \\
(\mathrm{ft})\end{array}$} & \multicolumn{9}{|c|}{ Flood heights, feet above mean sea level } \\
\hline & & \multicolumn{9}{|c|}{ Recurrence interval, in years } \\
\hline & & 2 & 2.33 & 5 & 10 & 25 & 50 & 100 & 200 & 500 \\
\hline 60 & 86,900 & 51.1 & 51.4 & 53.3 & 54.9 & 56.6 & 57.9 & 59.0 & 60.0 & 61.5 \\
\hline 62 & 89,400 & 51.6 & 51.8 & 53.4 & 55.0 & 56.6 & 57.9 & 59.0 & 60.0 & 61.5 \\
\hline Sec. 20E, T26S, R19E $\frac{1 /}{1 /}$ & 89,400 & -- & -- & -- & -- & -- & -- & -- & -- & -- \\
\hline Sec. 17S, T26S, R19E $\frac{17}{1}$ & 89,700 & -- & -- & -- & -- & -- & -- & -- & -- & -- \\
\hline Sec. $16 \mathrm{~W}, \mathrm{~T} 26 \mathrm{~S}, \mathrm{R} 19 \mathrm{E}=$ & 90,000 & -- & -- & -- & -- & -- & -- & -- & -- & -- \\
\hline 64 & 92,400 & 52.3 & 52.4 & 53.5 & 55.0 & 56.6 & 57.9 & 59.0 & 60.0 & 61.5 \\
\hline 66 & 95,400 & 52.7 & 52.8 & 53.6 & 55.0 & 56.6 & 57.9 & 59.0 & 60.0 & 61.5 \\
\hline Sec. 9S, T26S, R19E & 95,500 & -- & -- & -- & - & - & -- & - & - & -- \\
\hline 68 & 98,400 & 53.2 & 53.4 & 54.0 & 55.1 & 56.7 & 57.9 & 59.0 & 60.0 & 61.5 \\
\hline 70 & 100,800 & 55.1 & 55.2 & 55.7 & 56.0 & 56.8 & 58.0 & 59.0 & 60.0 & 61.5 \\
\hline Sec. 4S, T26S, R19E- & 102,100 & -- & -- & -- & -- & -- & -- & -- & -- & -- \\
\hline 72 & 103,100 & 56.0 & 56.1 & 56.6 & 57.0 & 57.2 & 58.1 & 59.1 & 60.0 & 61.5 \\
\hline Tributary 1 & 103,400 & -- & -- & -- & -- & -- & -- & -- & -- & -- \\
\hline 74 & 107,200 & 56.6 & 56.7 & 57.2 & 57.6 & 57.9 & 58.4 & 59.2 & 60.1 & 61.5 \\
\hline Sec. 33S, T25S, R19E & 108,900 & -- & - & -- & -- & -- & -- & - & -- & -- \\
\hline 76 & 110,200 & 57.2 & 57.3 & 57.7 & 58.1 & 58.4 & 58.8 & 59.4 & 60.2 & 61.6 \\
\hline 78 & 113,400 & 57.8 & 57.9 & 58.3 & 58.7 & 59.1 & 59.3 & 59.8 & 60.3 & 61.6 \\
\hline Sec. 18S, T25S, R19E & 115,270 & -- & -- & -- & -- & -- & -- & -- & -- & -- \\
\hline 81 & 117,400 & 59.6 & 59.7 & 60.0 & 60.4 & 60.9 & 61.2 & 61.5 & 61.6 & 62.0 \\
\hline 84 & 121,200 & 61.9 & 62.1 & 62.5 & 62.9 & 63.3 & 63.5 & 63.8 & 64.0 & 64.3 \\
\hline Sec. 21S, T25S, R19E $1 /$ & 123,000 & -- & -- & -- & -- & -- & -- & -- & -- & -- \\
\hline 86 & 124,400 & 62.7 & 62.9 & 63.3 & 63.7 & 64.0 & 64.2 & 64.4 & 64.6 & 64.9 \\
\hline Sec. $22 \mathrm{~W}, \mathrm{~T} 25 \mathrm{~S}, \mathrm{R} 19 \mathrm{E}^{1 /}$ & 126,200 & -- & -- & -- & -- & -- & -- & -- & - & -- \\
\hline 88 & 127,700 & 63.4 & 63.5 & 63.9 & 64.2 & 64.6 & 64.8 & 65.1 & 65.3 & 65.5 \\
\hline 90 & 130,900 & 64.2 & 64.3 & 64.7 & 65.1 & 65.5 & 65.8 & 66.0 & 66.2 & 66.5 \\
\hline
\end{tabular}


Table 7. -- Computed flood heights for selected recurrence-interval flood-peak discharges at 53 cross sections on Cypress Creek from mouth to State Road 52 - continued

\begin{tabular}{|c|c|c|c|c|c|c|c|c|c|c|}
\hline \multirow{3}{*}{$\begin{array}{l}\text { Cross } \\
\text { section }\end{array}$} & \multirow{3}{*}{$\begin{array}{l}\text { Distance } \\
\text { above } \\
\text { mouth } \\
\text { (ft) }\end{array}$} & \multicolumn{9}{|c|}{ Flood height, feet above mean sea level } \\
\hline & & \multicolumn{9}{|c|}{ Recurrence interval, in years } \\
\hline & & 2 & 2.33 & 5 & 10 & 25 & 50 & 100 & 200 & 500 \\
\hline \multirow{2}{*}{ Sec. $15 \mathrm{~S}, \mathrm{~T}_{92} 25 \mathrm{~S}, \mathrm{R} 19 \mathrm{E}^{1 /}$} & 131,100 & -- & -- & -- & -- & -- & -- & -- & -- & -- \\
\hline & $\begin{array}{l}133,600 \\
134,800\end{array}$ & 65.8 & 66.0 & $\begin{array}{r}66.5 \\
--\end{array}$ & 66.9 & 67.2 & $\begin{array}{r}67.5 \\
--\end{array}$ & 67.7 & 67.8 & 68.0 \\
\hline Sec. $14 \mathrm{~W}, \mathrm{~T}_{94} 55 \mathrm{~S}, \mathrm{R} 19 \mathrm{E}^{-1 /}$ & 136,200 & 68.3 & 68.5 & 69.4 & 69.9 & 70.4 & 70.6 & 70.8 & 71.0 & 71.3 \\
\hline \multirow{2}{*}{ Sec. 11s, $\stackrel{96}{\mathrm{~T} 25 \mathrm{~S}, \mathrm{R} 19 \mathrm{E}^{1 /}}$} & 139,100 & 72.0 & 72.3 & 73.2 & 73.8 & 74.4 & 74.8 & 75.0 & 75.2 & 75.8 \\
\hline & 139,100 & -- & -- & -- & - & $-\bar{c}$ & -- & -- & -- & -- \\
\hline $98_{6 /}$ & 142,000 & 74.3 & 74.5 & 75.1 & 75.5 & 76.0 & 76.3 & 76.6 & 76.8 & 77.2 \\
\hline $99-1$ & 142,100 & 74.3 & 74.5 & 75.2 & 75.6 & 76.0 & 76.3 & 76.6 & 76.7 & 77.0 \\
\hline
\end{tabular}

1/ Land-section line (east, north, south, or west), township, and range at intersection with Cypress Creek.

2/ Gaging station near Sulphur Springs (State Road 581).

3/ Interstate Highway 75.

4/ Gaging station at Worthington Gardens (State Road 54).

5/ Seaboard Coastline Railroad.

6/ Gaging station near San Antonio (State Road 52).

* Road inundated.

+ Bridge inundated. 


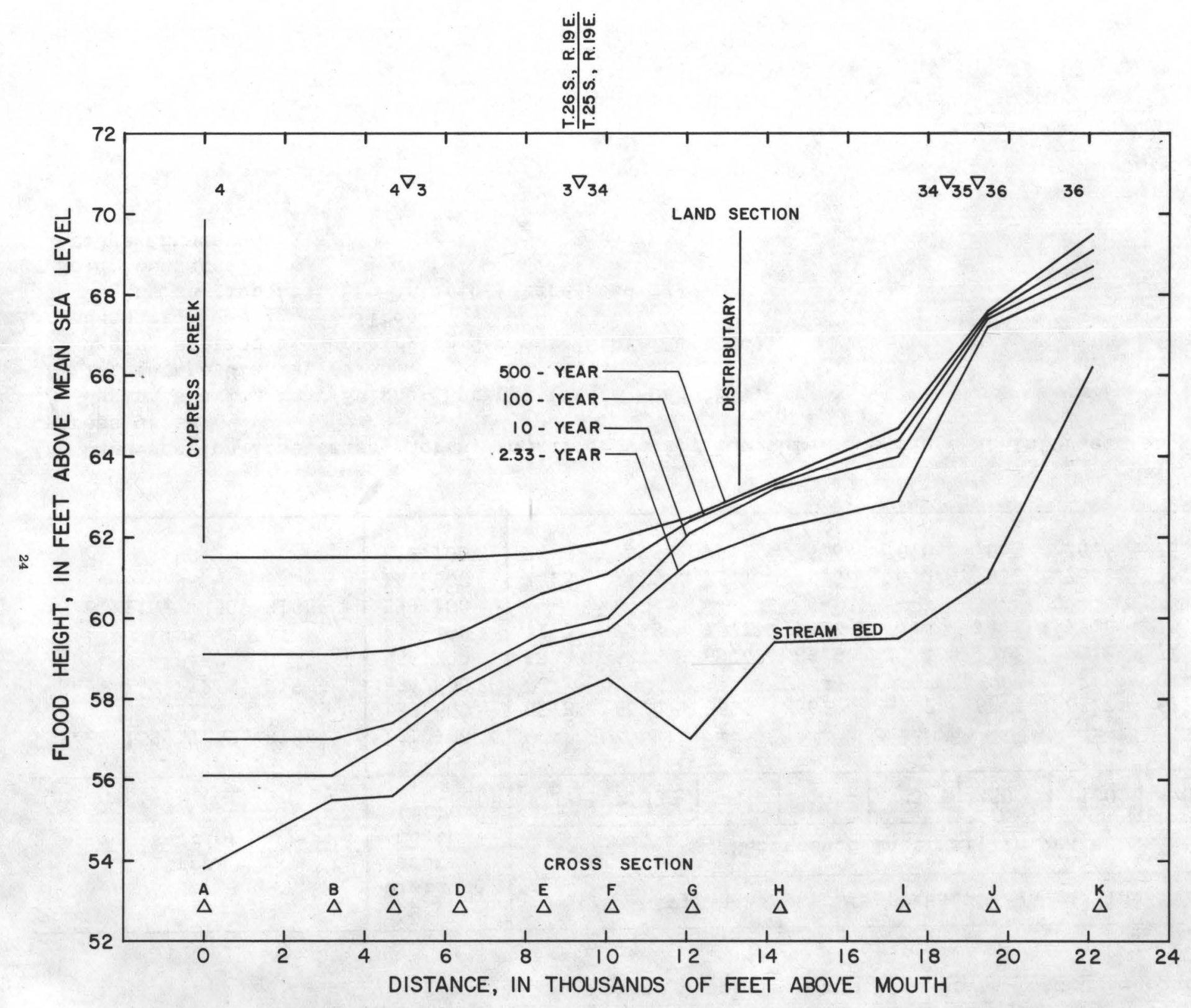

Figure 6.--2.33-, 10-, 100-, and 500-year flood profiles for Tributary 1 study reach. 
Table 8. -- Computed flood heights for selected recurrence-interval flood-peak discharges at 11 cross sections on Tributary 1

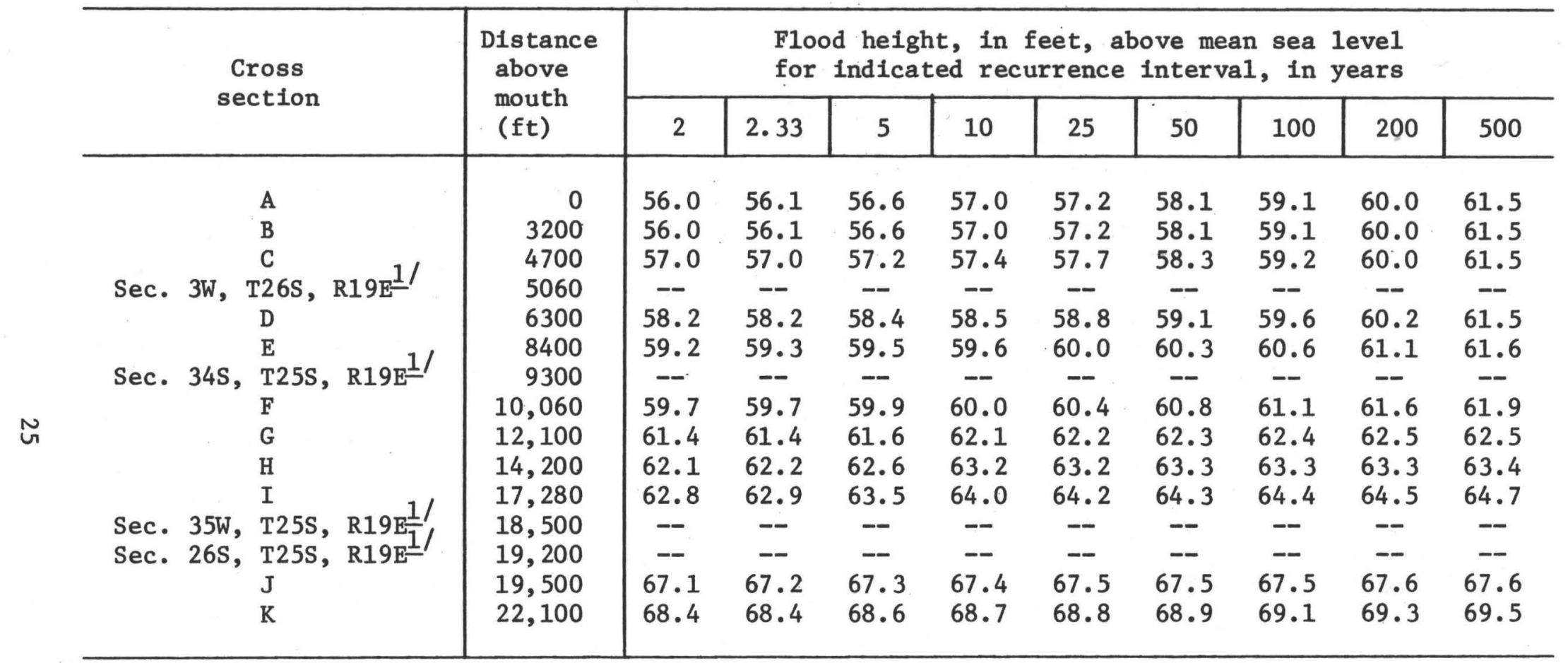

I/ Land-section line (east, north, south, or west), township, and range at intersection with Tributary 1 . 
T. 25 S., R. 19 E.

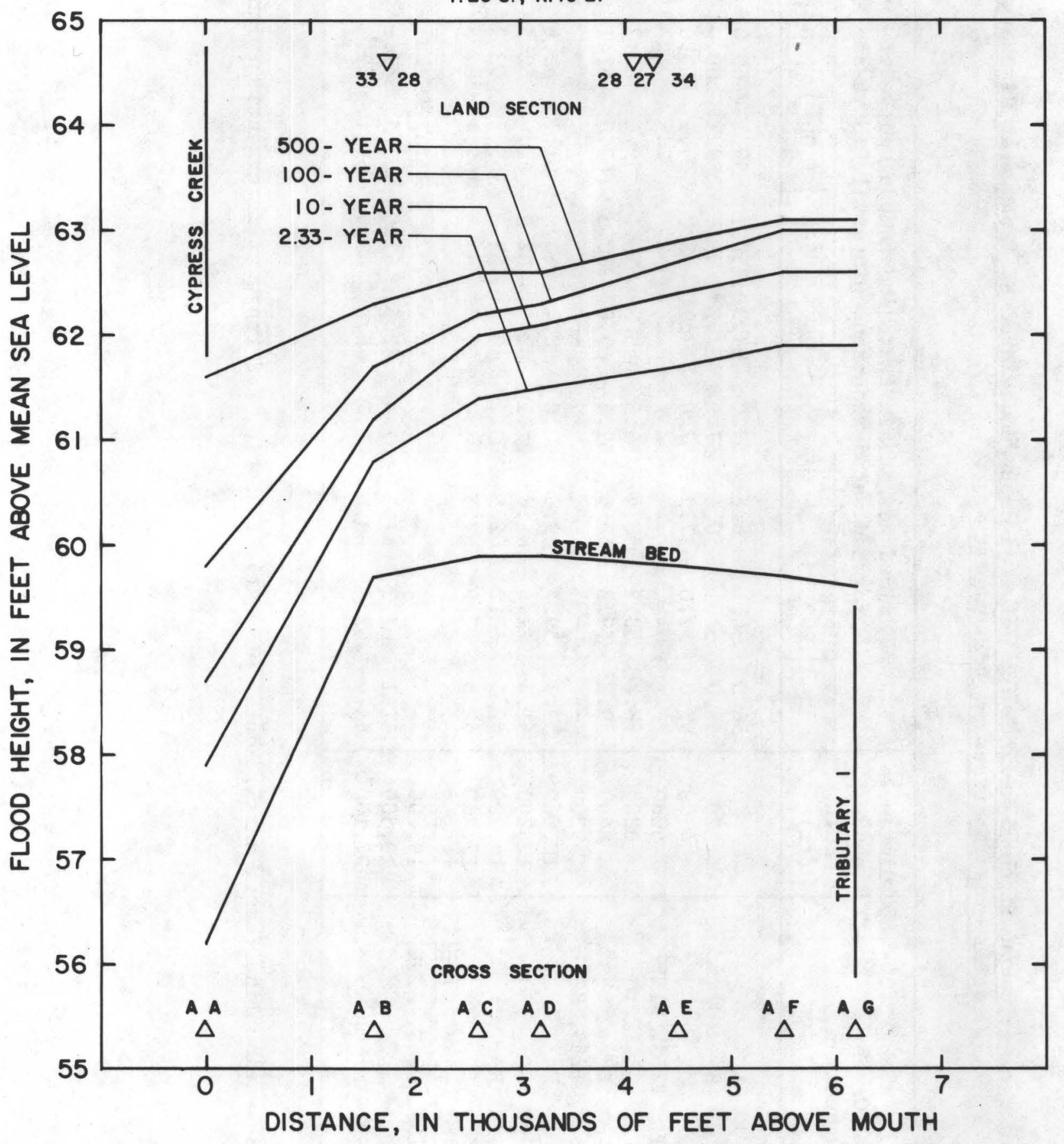

Figure 7 -- 2.33-, 10-, 100-, and 500-year flood profiles for the distributary 
Table 9. -- Computed flood heights for selected recurrence-interval flood-peak discharges at 7 cross sections on the distributary

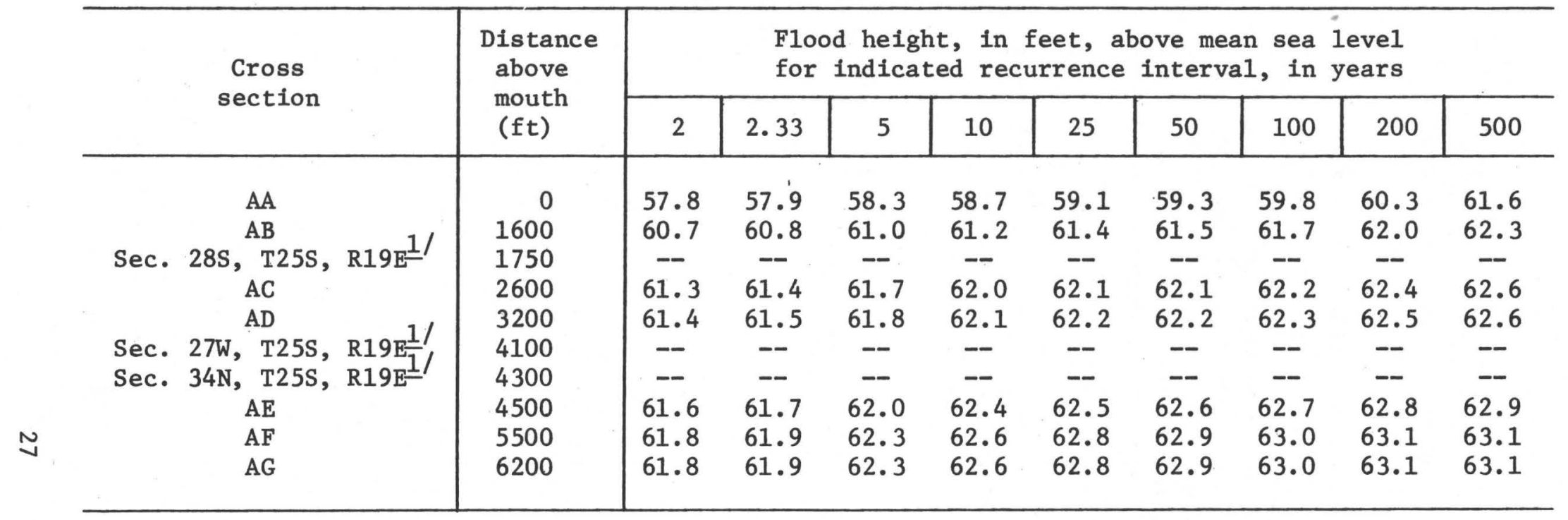

I/ Land-section line (east, north, south, or west), township, and range at intersection with distributary. 
Cypress Creek is a principal tributary to the Hillshorough River in west-central Florida, and drains an area of about $164 \mathrm{mi}^{2}$. Developments are increasing in the basin; some are in flood-prone areas along the lower Cypress Creek main stem.

Flood heights, having recurrence intervals of $2,2.33,5,10,25$, $50,100,200$, and 500 years, were computed for a 27-mi reach of lower Cypress Creek, for a 4-mi tributary reach, and for a 1.2-mi distributary. Magnitude and frequency of floods used were determined from Cypress Creek streamflow records and results of a regional flood analysis. The regional analysis was based on streamflow records for 20 gaging stations in westcentral Florida, each having 20 or more years of record. F]ood profiles are included for 2.33-, 10-, 100-, and 500-year recurrence intervals. The State Road 581 Cypress Creek bridge and the road near the bridge are expected to be inundated.

Cypress Creek is affected by backwater from Hillsborough River, upstream to, or beyond, the Cypress Creek near Sulphur Springs gaging station.

Flood heights provided as part of this report can be used to delineate the areal extent of flooding on topographic maps. Computed flood heights are judged to be accurate to $-0.5 \mathrm{ft}$. These data represent current basin conditions and may not be applicable after significant further development.

\section{SELECTED REFERENCES}

Bailey, J. F., and Ray, H. A., 1966, Definition of stage-discharge relation in natural channels by step-backwater analysis: U.S. Geo1. Survey Water-Supply Paper 1869-A, 24 p.

Barnes, H. H., and Golden, H. G., 1966, Magnitude and frequency of floods in the United States, Part 2-B. South Atlantic Slope and Eastern Gulf of Mexico basins, Ogeechee River to Pear1 River: U.S. Geol. Survey Water-Supply Paper 1674, 409 p.

Bryant, Edward C., 1960, Statistical analysis: New York, McGraw-Hill, 321 p.

Chow, V. T., 1959, Open channel hydraulics: New York, McGraw-Hill, p. 106-109. 265-268.

Dalrymple, Tate, 1960, Flood-frequency analysis: U.S. Geo1. Survey Water-Supply Paper 1543-A, 80 p.

Ezekiel, M., 1950, Methods of correlation analysis, 2d ed., New York, John Wiley and Sons, Inc., 531 p. 
Hardison, C., 1969, Accuracy of streamflow characteristics: U.S. Geol. Survey Professional Paper 650-D, p. D210-D214.

Langbein, W. B., and Iseri, K. T., 1960, General introduction and hydrologic definitions: U.S. Geol. Survey Water-Supply Paper 1541-A, 29 p.

Linsley, R. K., Kohler, M. A., and Paulhus, J. L. H., 1958, Hydrology for engineers: New York, McGraw-Hil1, 689 p.

Posey, C. J., 1950, Gradually varied channel flow, in Rouse, H., ed., Engineering hydraulics: New York, John Wiley and Sons, p. 625-629.

Pride, R. W., 1962, Floods at Tampa, Florida: U.S. Geol. Survey Hydrol. Inv. Atlas HA-66.

Rabon, James W., 1971, Evaluation of streamflow-data program in Florida: U.S. Geol. Survey open-file rept. 70-008, 70 p.

Riggs, H. C., 1968, Frequency curves: U.S. Geol. Survey Techniques Water-Resources Inv., book 4, chap. A2, 15 p.

Shearman, J. 0., 1976, Computer applications for step-backwater and floodway analyses: U.S. Geol. Survey open-file rept. 76-499, 175 p.

Turner, J. F., 1974, Flood profiles of the lower Hillsborough River, Florida: U.S. Geol. Survey open-file rept., $28 \mathrm{p}$.

U.S. Water Resources Council, 1976, Guidelines for determining floodflow frequency: Bul1. 17, U.S. Govt. Printing Office, Washington, D. C. 
UNITED STATES DEPARTMENT OF THE INTERIOR GEOLOGICAL SURVEY

325 John Knox Rd--Suite F240

Tallahassee, Florida 32303
POSTAGE AND FEES PAID

U.S. DEPARTMENT OF THE INTERIOR

INT. 413

\section{FIRST CLASS}

